\title{
Religious Populism and Public Sphere in Indonesia
}

\author{
Robertus Wijanarko \\ Sekolah Tinggi Filsafat Teologi Widya Sasana, Malang \\ rwijanarko68@gmail.com
}

Received: 20/01/2021.

Reviewed: invited author.

Published: 28/04/2021.

Copyright $\odot 2021$ by the author (et al) and Jurnal

Sosial Humaniora (JSH)

*This work is licensed under the Creative Commons

Attribution International License (CC BY 4.0).

http://creativecommons.org/licenses/by/4.0/

\begin{abstract}
Subject Area: Philosophy
Abstract

Religious populism has strong and profound influence in Indonesia. It challenges the rational foundation of the democratic structure of the Indonesian Politics. This populist political movement utilizes religious language and symbols as their language of political articulation, negotiation, and contestation, which then occupies the real and virtual public sphere of the politics of Indonesia. Therefore, this use of religious language and symbols has placed democratic system in a serious risk. This critical study is intended to investigate the disadvantages of the use of religious language and symbols in the political arena in Indonesia. I will employ Paul Ricour's thoughts in his writing, The Fragility of Political Language, as a lens of analysis for that phenomenon. Through that analysis I argue that the use of religious language and symbols in political discourse contradicts the provisional character of political language in democratic political settings. I suggest, therefore, the reenactment of the constitutional and rational foundation of democratic structure of Politics in Indonesia is seriously required.
\end{abstract}

Keywords: populist; religious populism; public sphere; political language; reenactment

\section{Introduction}

In the constitutional nation-state of the Republic of Indonesia, Populism is a form of political regression. Indonesia had committed to overcome the politics of "tribalism", or of sectarian identity when the young generations, -Jong Java, Jong Ambon, Jong Celebes, to name several-, in 1928 declared their dream to build one nation on the basis national unity (nationalism). By that declaration, their imagination of the national community moved beyond sectarian margins (Anderson, 1991). This declaration for national unity is confirmed by the political decision of the nation-state after independence to build political system on the foundation of modern constitution and rule of laws. Constitution and national laws then became a rational foundation of the national state to build a political system and structure.

However, in the last two decades, -around 75 years after independence, it become increasingly obvious that new religious populism is played as a political movement or strategy, designated to challenge the establishment, with its rational and constitutional legitimacy (Hardiman, 2017). This contemporary form of religious populism, I argue, is a form of political regression, since this political movement utilizes forms of sectarian political sentiment as instrument for political contestation. This political movement, affiliated with particular religious community, utilizes Religious language and symbols to articulate their aspirations and 
interests. It influenced and even dominated political discourses in the public sphere. It can be used for mass mobilization as well to force their message and interest to the establishment or other political groups.

Moreover, in the era of the revolution of digital information and the development of social media, not only does the use of religious language and symbol challenge the effort to build a solid and rational public sphere, it also creates virtual public sphere which endangers traditional fundamental pillars of democracy. Virtual public sphere, I believe, delimits the rational process of political deliberation, and endangers rational character of public sphere, since in many cases it heavily manipulates the emotional or sentimental aspect of the people. Whereas the critical thinking has not been part of cultural tradition of the Indonesian people. The advent of the Covid-19 pandemic has intensified the use of the virtual-digital media in creating virtual public sphere. And to some extent, it could also disrupt the traditional mechanisms and procedures of the democratic system. It is obvious, therefore, that the use of religious language and symbols in political discourse, complicated with the development of virtual public sphere, has caused the rational dimension of political realm marginalized.

Given those conditions, I would critically investigate the use of religious language and symbols in the political discourse, which I deem endangering the rational aspect of public sphere. The emerging phenomenon of the virtual public sphere, which is intensified by the phenomena of Covid-19 pandemic, will also be considered in this study. I will utilize Paul Ricoeur's thoughts on The Fragility of Political Language as the framework of this philosophical critical analysis (Ricoeur, 1987). Through this procedure I will exhibit that the rational (constitutional) foundation of the national state of Indonesia need to be rearticulated. It is only if this rational aspect of political system be strengthened, the aspiration to build a strong democratic system of politics will be possible. And this rational aspect of public sphere can be reinforced by means of the rational use of political language in the public discourse. In order to achieve that objective, I shall organize this article into following structure: first, I will clarify what Populism is. Second, I will illustrate the genesis of populism in Indonesia. In this section I will also exhibit the form of Religious Populism in Indonesia. Third, I will explore the impact of the Religious Populism, which utilized religious languages and symbols, for the future of the political public sphere in Indonesia. And fourth, I will propose several solutions to overcome the disadvantages and problem of Religious Populism.

\section{Literature Review}

\section{Populism as Political Movement}

Populism is basically a contested concept. Some thinkers such as Cas Mudde, Cristobal Rovira Kaltwasser, Jan-Warner Müller, consider Populism as a political ideology, some others such as Ernesto Laclau, Chantal Mouffe, and Lawrence Goodwyn, as political doctrine, strategy, or movement (Mudde \& Rovira Kaltwasser, 2017; Muller, 2016). Without undermining other positions, in this paper I identify Populism as a political movement, since this political articulation appears through political movement, with programmatic strategy, regardless of their ideological orientation. This is more a movement of the peoples, I believe, since it does not have to have a strong, solid, and comprehensive system of thought, such Communism, Socialism, or 
Liberalism. This political movement, however, usually is combined with other ideologies, existing in several countries, such as Socialism (Venezuela), Liberalism (European countries), Nationalism (North America) or even with particular religious groups (The USA and Indonesia). This populist movement can grow among labors, farmers, ethnic or racial group, or other groups that are economically, socially, and politically marginalized.

Political populism carries with it several characteristics (Babić, 2019; Muller, 2016). First, Populism is a movement of peoples who claim themselves as "populum" or "common people". These peoples identify themselves as the only group of people that represents and articulates the voice of the common people. They struggle and fight for the real people, for their rights and interests. Therefore, when this group of people gains power, they do not recognize opposition; for them no opposition is needed and legitimate. Second, populists differentiate themselves from the elites, to be critical to the elites and the establishment. They divide social reality into two different groups, namely the elites and the real peoples. They identify the elites, which do not fight for their aspiration and benefits, as a corrupt and immoral. For populists, the elites are groups of social and political class that possess economic, social, and political privileges they do not deserve. These elites, according to the populists, manipulate peoples' voices for the sake of their own interests and agenda. Third, populists are anti-pluralism and democracy, since they believe that only their group carry the voice, interests, and rights of the real people. They believe that only their group is able to transform the existing corrupt system. Therefore, for them, political deliberation is not needed. Fourth, they deify the communal character of the real peoples and the communal nature of human existence. In so doing, they reduce individuals to become simply as a part of, or a component of the communal entity, which they name "populum". The fundamental rights of the individuals are suppressed under the idea of "populum", as if populum is a metaphysical category, without existential reference, which is highly plural and diverse in many aspects of human existence.

Populism is a political movement of the peoples, which combines their populist movement with particular political orientations. In general, peoples then differentiate right-wing and left-wing populism. Right-wing populism is associated with populist movements that connect with nationalism, while left-wing populism is associated with socialist political orientation. In reality, given the political constellations, a populist movement can collaborate with many different group affiliations, such as labors, peasants, ethnic, or religious tradition groups. Both right-wing populism and left-wing populism, however, criticize and object to the domination or control of liberal democracies. I am convinced that, to some extent, liberal democracy gives birth to political populism. In the sense that, in one hand, liberal democracy gives a room for freedom of civil association, which enables people to build their group association. On the other hand, the objective of liberal democracy, which is to create political structure and procedure that provide equal rights and opportunity among members of the society and create common good, cannot be achieved. Many examples show that liberal democracy cannot reduce the political and economic gap between the members of the society. This system of liberal democracy, combined with the trends of economic liberalism-capitalism and globalization, as many examples show, even put many groups of society marginalized. Such a kind of "dysfunctional" liberal democracy can be found in the political system in Indonesia. Since, although claiming to embracing 
"Democracy of Pancasila", as a matter-of-fact Indonesia inclines to practice liberal democracy, which is strongly influenced directed by the system of economic liberalism-capitalism and globalization.

\section{Discussion}

\section{Populism in Indonesia}

I will not elaborate a historical origin and development of Populism in Indonesia. I would rather exhibit existential stance, which argues that populism arises when people find that they are marginalized. They cannot pursue their aspirations, ideals, and dreams. They find that the existing socio-economic-political system does not open the room for them to achieve fundamental needs for their life. This can be considered as the origin of the existence of populism in Indonesia. Theoretically speaking, Populist movement came into existence when some members of the given society feel marginalized. It started when they found that their dream and aspirations, could not find place to be realized. This signifies that the existing democratic system and procedure do not function well.

There are several conditions that initiate the growth of Populism in Indonesia. The first condition is the communal character of Indonesian people, coming from almost all ethnic community, which then constructs the idea of Indonesian nationalism. Traditional communality of Indonesia emphasizes the communal value of the social entity, which considers communality as a very important value, which in some cases reduces individuals simply as members of the community. The awareness of the individual rights inclines to be submerged under the idea of communality. The second condition is the socio-economic-political gap, which has been broaden during the period of military authoritarian climate of the New Order (Orde Baru) regime, which is still perpetuated continuously by new regimes until today. Several different regimes have changed in Indonesia, however they unable to make social-political-economic transformation. Back to the New Order regime. This gap creates a context for the growth of Populism, since such condition marginalizes some groups of people. The marginalized people would eventually strive to build a political power by articulating the power of the common people (populum) and criticizing the ruling power which, for them, betray their promise to fight for civil justice, equality, and prosperity.

The third condition is the dysfunctionality of liberal democracy (or Democracy of Pancasila). The perpetuation of the social-economic-political gap shows that the existing political system, namely liberal democratic system, does not function well. What really happens is only the development of "procedural democracy." Indonesia has already constructed democratic political structure, constituted regular general election process for legislators and executive leaders, and practiced familiar procedure of democratic system, but those democratic exercises remain only at the formalistic level. And this procedural democracy is unable to create a just, equal, and prosperous society, giving room for populist movements to grow, as people strive to find alternative political strategies to open access to the economic, social, and political domination.

Finally, the fourth condition is the process of "mainstreaming" the conservative religious stance which has attracted many people, in need of identity and definitive principles in the face of uncertain system of values as an effect of globalization (Hadiz, 2019). This process of mainstreaming conservative religious beliefs goes 
hand in hand with the need to build a basis of political group, which is affiliated with religious community. This process ends up in the emergence of religious populism in Indonesia. In order to attract the followers, the political (and religious) leaders of this religious populist movement utilize religious language and symbols as form of rhetoric and articulation. The use of political symbols and language that are derived from religious materials and practices is powerful, since it can influence emotions, attract militant-faithful followers rapidly, and functions as instruments for mass mobilization. This use of political language and symbols has already strongly influenced the political discourse of the political contestation in Indonesia. This means that political languages and symbols, articulated by religious populist groups, have affected the formation of public sphere of Indonesian politics. In the course of time, this religious populism also creates exclusive theological reflections that is suitable to support their movement. Religious populist groups offer legitimate theological foundations for their religious populist movements. Taking this condition seriously into consideration, we need then to reflect further the correlation of Religious Populism, which strongly utilize the religious language and symbols in their political rhetoric and articulation, with the formation of Public Sphere.

\section{Religious Populism and Public Sphere}

According to Jürgen Habermas the public sphere is an arena "made up of private people gathered together as a public and articulating the needs of society with the state" (Habermas, 1989). The political public sphere is an arena of political contestation and negotiation. In this public arena political discourse takes place. Political programs and promises are also articulated in this public sphere. We can identify political affiliation of different groups through their political articulations. What peoples consider as the objective of political programs, which serves for the realization of common goods (Bonum Communae), are articulated, contested, criticized, and negotiated in this arena. What peoples agreed upon and committed as common goods are deliberated in this political arena. The new challenge of the public sphere came from the intensive utilization of digital technology and social media (as several examples: YouTube channel, Facebook, Twitter, WhatsApp, Line, and Instagram) in the political discourse. This new trend facilitated the emergence of a new digital public sphere withs its consequences. The emotional aspect of human being become more vulnerable as a target of political propaganda and manipulation. This complicated problem of new public sphere is intensified by the Religious Populism, which utilize religious languages and symbols in digital political discourse. An important study related to the use of the digital technology and social media for political articulations and contestation in Indonesia, to mention an example, was conducted by Merlyna Lim, as she published under title Freedom to hate:social media, algorithmic enclaves, and the rise of tribal nationalism in Indonesia (Lim, 2017). At the time of Covid-19 pandemic, when the social distancing is strictly applied, the use of digital technology and social media in the political arena increases. Therefore, the fabrication of social community, due to the use of religious languages and symbols in the virtual public sphere, is magnified. Nowadays, the public sphere and virtual public sphere in Indonesia have been dominated by the use of religious language and symbols for the political rhetoric and discourse. The rational aspect of public sphere, therefore, is in serious danger. Public sphere becomes an arena of cruel political contestation, heavily colored by hate-speechs, which violently attacks and marginalize different political groups. In order to reflect ritically on the impact of the use of 
religious language and symbols in political discourse, I will utilize Paul Ricoeur's approach in his writting Fragility of Political Language.

In my reading of Paul Ricoeur's writing, The Fragility of Political Language, Ricoeur argues that the Fragility of Political Languge can be traced in three different leves. First, at the level of public discourse (Ricoeur, 1987). In a democratic system, public sphere is an essential element, or conditio sine qua non for the democratic system. Without the public sphere, democracy will simply become a meaningless rhetoric or jargon. Public sphere is an arena in which political discourse is exercised. Public sphere keeps democratic atmosphere alive. In this arena, political ideals and orientation are articulated by means of political language and symbols. It is in this public arena that political language and representation are being contested, criticized, challenged. In the democratic system, every political discourse is never intended to find a final truth and ultimate political concept or solid political ideals. Every political language and symbol are articulated not to find a comprehensive, absolute, or final consensus. It is rather intended to find provisional terms or political language and idealism that can be agreed as a tentative consensus, which then can be translated into a concrete political program and actions (Ricoeur, 1987). It is in this context that political language is fragile. Political debates, discussions, contestations, and deliberations are not intended to find absolute truth or terms, but it is intended to achieve the best possibility of political formulation, although it is limited and will be agreed, based on consensus. It is in this context of the fragility of political language that the use of religious language and symbols and the articulation of religious concept from any religious tradition in the political discourse could be problematic. It is problematic since the religious concepts and language tend to be claimed as an absolute and final truth, while the political language is not intended to create such definitive and final truths (Wijanarko, 2000).

Second, the fragility of political language becomes more obvious, Ricoeur argues, when it is reflected in the context of political ideal and the objective of good government, which is to facilitate "common good" or Bonum Communae (Ricoeur, 1987). At this level the central themes of political discourse are justice, freedom, equality, and prosperity. Since such themes carry with them emotional power, due to its character to unite peoples and motivate them to pursue their essential and fundamental needs, those terms are very prone to be manipulated and to became instrument of propaganda. This is to say, those political languages related to those themes, can be utilized as weapon for mass mobilization, rather than to be utilized to articulate valuable and rational political conceptions. In the political contestation those powerful terms, such as justice, freedom, equality, prosperity, can be manipulated to insert other values or system of beliefs, instead of being used to articulate the authentic meaning of those terms. It is in this point that the potency of the conflictual contestation come into being. As Ricoeur wrote, "Essentially, it signifies that the historical realization of a particular set of values cannot be attained without doing some injustice to another such set, that the tragic aspect of all human action is unavoidable, and that no one can serve every value at the same time" (Ricoeur, 1987). Since politicians can utilize those political terms, to advance various different interests, the need to determine priority upon the values that need to be carried out by those terms, and the degree of relativity of meanings and of the quality of those values, - due to the different historical, geographical, social, and cultural context, causes those values to become ambiguous and fragile. In the meantime, those political terms, and their ambiguous 
interpretations should be accepted by many through consensus, to formulate public policies, that affect and regulate many people's lives. Consequently, partial understandings and interpretations of those terms by particular religious groups in many cases potentially trigger serious conflicts. At this degree, we find a paradox of the use of religious language in political discourse, due to the provisional character of political language, in one hand, and the orthodox-conservative character of religious views which are verbalized through religious language and symbols, on the other hand (Wijanarko, 2000).

Third, the fragility of political language can also be identified, Ricoeur wrote, when we reflect on the horizon of societal values (Ricoeur, 1987). It is in this horizon that the ideas of a good government can be accorded with the form of what considered as a good life. At this level Ricoeur exhibits that in reality political languages are not only ambiguous but also ambivalence. Political language is ambivalent since the values carried out are also ambivalent. This can be reflected from the fact that human beings can both love and hate the same things, for good and reasonable reasons. Human beings can receive and reject the same values. This ambivalent character continues no matter by what terms those values verbalized. In such perspective, when the ruling government decided to select a series of values to pursue, those values are formulated in certain political languages, and those values will be measured and criticized by peoples based on their different system of values (horizons). In modern society this phenomenon takes its form in the crisis of legitimacy (Ricoeur, 1987). This kind of crisis of legitimacy is not related to the disobedient attitude to the ruling government, nor crisis of identity of the citizens in the face of existing government. It is rather an uncertainty that the ideals that has been selected and committed are the values that are supposed to be selected and pursued. In relation to this thought, Ricouer identifies that modern soceity has been trapped into the modernism paradox, in which they cannot find "self-identity" (self-interpretation of modern existence) from what they decided and promoted as it is instituted in the legal system of democracy. Modern society has been trapped to love what they hate, without any alternative to turn their way around to build society and define their identity. For example, the modern society has determined "development" as their ideal, so that they place prosperity corresponding to justice, equality, and freedom which they already instituted in their constitution. At the same time, the modern society is also being disturbed by the doubt of whether "the development" they intended is value that needs to pursue as their ideal. Moreover, modern society, with many new inventions and innovations of technology, related to the artificial human needs, in its turn it affects human attitudes that never be satisfied and stop their effort to pursue their new needs. This condition strengthens their doubt of value of "development". Eventually, the development they already selected as their ideal of humanization can be loved or be suspected or even be hated. Reflecting on Ricoeur's analysis on this level, we could see that the use of religious languages and symbols in political rhetoric could make the ambiguous and ambivalent character of political language becoming more complicated. When religious language is applied in political discourse, what is being employed is not simply religious vocabularies, but articulations of systems of values, which need to be comprehended on the basis of horizon of values of its sitz im leben. It means that religious values, views, and terms which incline to be absolute-conservative-dogmatic, can burden the ideals to build society (Wijanarko, 2000). In the context of Indonesia, the issue become more complicated, owing to the plurality of religious traditions and multicultural condition. 
Paul Ricoeur's analysis of the fragility of political language enables us to see the disadvantages and challenges of the use of religious language and symbols in political discourse. It will contradict with the nature of public sphere in the constitutional democratic political setting. When we reflect more profoundly on this kind of political articulation, it will become more obvious that populist movement naturally is anti-pluralism. Since they do not believe in opposition, the democratic political deliberation in the public sphere will certainly not be needed. Therefore, religious populism, which emerges in the setting of liberal democratic system, will destroy system of democracy itself. Furthermore, in the recent Covid-19 pandemic, the use of digital technology and social media for political propaganda become increasingly massive, the use of political language and symbols could extinguish culture of democracy. In conclusion, religious populism with its religious rhetoric needs to be challenged.

\section{Conclusion}

\section{Reenacting Rational Foundation of Democratic and Constitutional System.}

Indonesia has committed to build a nation state under foundation of the democratic constitutional state. This is the rational foundation of the political public sphere in this multicultural country. Political articulation, negotiation, and contestation among the members of this constitutional state, regardless of their cultural background or religious affiliation, must be oriented under the guidance of this constitutional foundation. Political narrative and populist political rhetoric, built on the basis of sectarian identity, would be unsuitable with the desire to develop democratic political structure and culture. Therefore, the need for constitutional (rational) reenactment is really indispensable, especially at time when the social, cultural, and political identity are challenged by a new system of values, political orientation, and economic system carried by globalization.

The use of religious language and symbols in the political rhetoric has occupied not only existential public sphere but also virtual public sphere. At this level, emotional aspect of our human capacity could easily be manipulated for partial political purposes. During the Ccovid-19 pandemic, the penetration of digital communication means and social media intensify and may open more vulnerabilities as physical spaces for political debates shrink. Dependence on virtual public spheres raises questions on vulnerability to political predators or demagogues, who claim to fight for common peoples' aspirations and rights. Given that risk, I would suggest that religious language and symbols should not be utilized as political rhetoric in the democratic public sphere, both existential and virtual. Despite initiating a contradiction with the provisional nature of political languages, as Ricoeur argues, the use of religious language and symbol does not suit also with the nature of democratic deliberation process. Democratic political education and digital media literacy, therefore, would be seriously required. Moreover, due to provisional character of political language, the use of the political languages which promote universal values related to common human aspirations and needs, is highly recommended.

The absence of a strong civil society in democratic political system, among others, can be considered as a condition that promotes the growth of Religious Populism. In such a socio-political setting the individuals and human rights are not conceded. Instead, the individuals and their rights are reduced to communal 
dimension of society, as a communal entity. In the context of Indonesia, in which religious institutions are supposed to develop civil society, the civil society does not flourish, since the religious leaders and their institutions in many cases are co-opted to the ruling power. This condition that also hinders the development of democratic culture among the society. In order to build a strong democratic culture and system, and avoid the growth of religious populism, Indonesia needs to grow a strong rational, critical, and strong civil society.

\section{References}

Anderson, B. (1991). Imagined communities : reflections on the origin and spread of nationalism. London: Verso.

Babić, M. 1. (2019). Populism and Religion in Bosnia and Herzegovina. Concilium.

Habermas, J. (1989). The Structural Transformation of the Public Sphere: An Inquiry Into a Category of Bourgeois Society. (T. Burger, Ed.) (First). Cambridge, Massachusetts: MIT Press.

Hadiz, V. R. (2019). Populisme Islam di Indonesia dan Timur Tengah (Edisi Pert). Jakarta: LP3ES.

Hardiman, F. B. (2017). Kebangkitan Populisme Kanan dalam Negara Hukum Demokratis. Prisma: Jurnal Pemikiran Sosial Ekonomi, 36(2), 3-9.

Lim, M. (2017). Freedom to hate: social media, algorithmic enclaves, and the rise of tribal nationalism in Indonesia. Critical Asian Studies, 49(3), 411-427. https://doi.org/10.1080/14672715.2017.1341188

Mudde, C., \& Rovira Kaltwasser, C. (2017). Populism : a very short introduction (First Edit). Hants: Oxford University Press.

Muller, J.-W. (2016). What is populism? Philadelphia: University of Pennsylvania Press.

Ricoeur, P. (1987). The Fragility of Political Language. Philosophy Today, 31, 35-44.

Wijanarko, R. (2000). Mengkritisi Penggunaan Bahasa Agama dalam Wacana dan Kehidupan Politik. Seri Filsafat Teologi Widya Sasana, 101-110. 